Vol.25, No.2, Desember 2019

ISSN (p): 1693-590x, ISSN (e): 2686-4711

DOI: $10.36309 /$ goi.v25i2.106

\title{
Aplikasi Penyewaan Alat Outdoor pada Camel Adventure Surakarta Berbasis Android
}

\author{
Agung Nugroho ${ }^{1}$, Robby Rachmatullah ${ }^{2}$, Teguh Hananta Tri Artadi ${ }^{3}$ \\ ${ }^{1}$ Program Studi Teknik Komputer, STMIK AUB, Surakarta, Indonesia \\ ${ }^{23}$ Program Studi Sistem Informasi, STMIK AUB, Surakarta, Indonesia \\ e-mail: *1 agung_new@stmik-aub.ac.id, ${ }^{2}$ robby_r@stmik-aub.ac.id, ${ }^{3}$ teguhan@gmail.com
}

\begin{abstract}
Abstrak
Sebelumnya transaksi Camel Adventure proses pemesanan masih menggunakan pencatatan secara tertulis. Hal tersebut memerlukan waktu lebih bagi pengelola. Kendala yang dialami saat ini sulitnya pelanggan mengetahui stok yang masih tersedia dan proses penyewaan. Tujuan penelitian ini adalah membangun Aplikasi Penyewaan Alat Outdoor pada Camel Adventure Surakarta. Dalam membangun sistem tersebut metode pendekatan yang digunakan adalah metode perancangan dengan menggunakan metode waterfall. Metode pengumpulan data dengan metode wawancara, metode observasi dan metode pustaka. Sebagai alat bantu analisis dan perancangan yang digunakan adalah flowchart, UML ( Unified Moddeling Languange ), dan Entity Relationship Diagram. Sedangkan bahasa pemograman pendukung yang digunakan adalah Android Studio versi 3.0.1, PHP, Java, dan My SQL sebagai database. Hasil dari penelitian ini adalah membuat suat aplikasi penyewaan alat outdoor berbasis android yang dapat membantu pelanggan untuk meningkatkan transaksi yang akan dilakukan.
\end{abstract}

Kata kunci: Aplikasi, Penyewaan, Alat Outdoor, Android, PHP

\section{PENDAHULUAN}

Berkembangnya ilmu pengetahuan dan teknologi saat ini banyak mengakibatkan dampak dan tingkat ketergantungan manusia pada alat, model, dan sistem yang dapat membantu manusia untuk menyelesaikan persoalan dalam pekerjaan. Hal ini menyebabkan kehidupan manusia tidak lepas dari berbagai masalah yang semakin lama semakin kompleks dan membutuhkan pengetahuan yang lebih tinggi untuk dapat mengatasinya. Sangat wajar apabila sudah banyak perusahaan ataupun organisasi dan instansi pemerintahan maupun badan usaha yang memanfaatkan perkembangan teknologi informasi. Salah satunya dengan menggunakan sistem terkomputerisasi yang digunakan dalam membantu kebutuhan proses pekerjaan sehingga mempermudah dalam penyelesaian pekerjaan.

Dunia usaha harus meningkatkan sistem informasi guna menunjang daya saing. Tetapi fakta yang ada masih banyak perusahaan yang kurang memanfaatkan keberadaan teknologi yang semakin berkembang. Tanpa teknologi informasi, suatu perusahaan atau instasi tidak dapat menjalankan kegiatan operasional dalam ruang lingkup kerja secara optimal. Oleh karena itu, untuk menunjang kegiatan operasional dalam menyelesaikan pekerjaan, diperlukan suatu sistem informasi yang baik untuk mendapatkan data yang diperlukan akurat. Banyak instansi perusahaan besar memanfaatkan teknologi informasi sebagai alat bantu dalam menyelesaikan permasalahan yang sering dihadapi. Masalah ini dapat berupa informasi dari data-data yang ada kemudia diolah sesuai dengan kebutuhan.

Camel Adventure adalah perusahaan yang beralamat di Jl. Kartika No.8 RT 02/RW 21 Gulon, Jebres, Surakarta. Usaha ini bergerak di bidang jasa penyewaan alat outdoor, seperti

Received November 11, 2019; Revised November 25, 2019; Accepted December 9, 2019 
tenda dome, tas carrier, sleeping bag dan lain sebagainya. Namun dalam proses pemesanan masih menggunakan pencatatan secara tertulis. Hal tersebut memerlukan waktu lebih bagi pengelola Camel Adventure untuk mencatat data member dan data pemesanan alat outdoor.

Dari proses tersebut pihak Camel Adventure mulai melakukan pengembangan sistem yang masih kurang memadai. Semakin banyak peminat kini Camel Adventure mengoptimalkan usahanya dengan memanfaatkan teknologi informasi berupa sistem informasi persewaan alat outdoor agar lebih produktif dan informasi mudah didapat oleh member.

Kendala yang dialami saat ini yaitu sulitnya akses member dalam mengetahui stok yang masih tersedia dan proses penyewaan. Melihat hal tersebut, perlu diadakan pengembangan sistem informasi pada persewaan alat outdoor Camel Adventure dengan membuat aplikasi berbasis Android agar proses bisa di akses secara online melalui smartphone. Untuk selanjutnya dalam penyusunan Skripsi ini penulis menyajikan judul "Aplikasi Penyewaan Alat Outdoor Pada Camel Adventure”.

\section{METODE PENELITIAN}

\section{1 Metode Pengembangan Sistem}

Prosedur pengembangan yang digunakan pada aplikasi penyewaan alat outdoor ini adalah menggunakan prosedur pengembangan model Waterfall. Model ini melakukan pendekatan secara sistematis dan urut mulai dari level kebutuhan sistem lalu menuju ke tahap analisis, desain, coding, testing / verification, dan maintenance. Secara umum tahapan pada model waterfall dapat dilihat pada gambar 1 berikut.

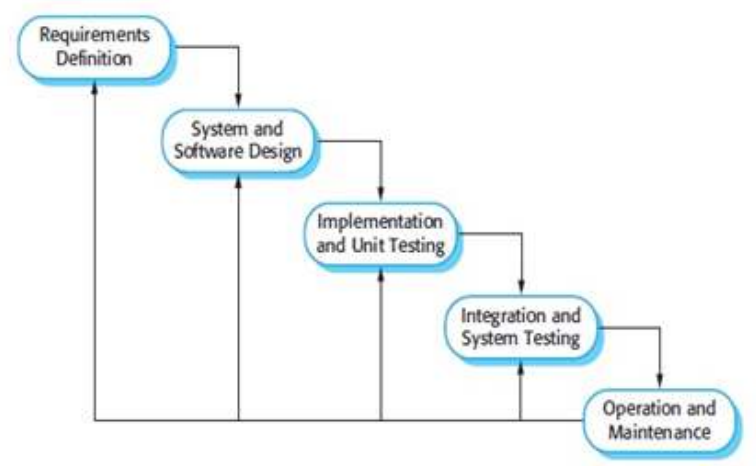

Gambar 1 Siklus Pengembangan Sistem dengan Metode Waterfall (Sommerville, 2011)

Pada gambar 1 Siklus Pengembangan Sistem dengan Metode Waterfall (Sommerville, 2011) adalah tahapan umum dari model proses ini. Berikut adalah penjelasan dari tahap-tahap yang dilakukan di dalam model ini:

a. Requirements definition. Pada tahapan ini penulis melakukan beberapa analisis di Camel Adventure Surakarta dimana dilakukan proses pengumpulan data, identifikasi masalah, dan analisis kebutuhan sampai aktivitas pendefinisian sistem kerja yang ada disana. Tahap ini bertujuan untuk menentukan solusi yang didapat dari aktivitasaktivitas tersebut.

b. System And Software Design. Pada tahap ini penulis membuat Aplikasi Penyewaan Alat Outdoor pada Camel Adventure Surakarta. Maksud pembuatan model ini adalah untuk memperoleh pengertian yang lebih baik terhadap aliran data dan control, prosesproses fungsional, tingkah laku operasi dan informasi-informasi yang terkandung didalamnya. Terdiri dari aktivitas utama pemodelan proses, pemodelan data dan desain interface.

c. Implementation And Unit Testing. Pada tahap ini penulis menganalisis Aplikasi Penyewaan Alat Outdoor Pada Camel Adventure Surakarta yang telah dirancang dan mulai diterjemahkan kedalam bahasa mesin melalui bahasa pemograman. Terdiri dari

GO INFOTECH: JURNAL ILMIAH STMIK AUB Vol. 25, No. 2, Desember 2019: 71 - 81 
dua aktivitas yaitu pembuatan kode program dan pembuatan interface program untuk Aplikasi Penyewaan Alat Outdoor Pada Camel Adventure Surakarta.

d. Integration And Sytem Testing. Selanjutnya penulis menguji program, yang dimana difokuskan pada pengujian logika internal Aplikasi Penyewaan Alat Outdoor Pada Camel Adventure Surakarta pemastian bahwa semua perintah yang ada telah dicoba, fungsi external untuk memastikan bahwa dengan masukan tertentu suatu fungsi akan menghasilkan keluaran sesuai dengan yang dikehendaki.

e. Operation And Maintenance. Pada tahap ini penulis menyiapkan perangkat keras dan lunak, menyiapkan database dan melatih pemakai Aplikasi Penyewaan Alat Outdoor Pada Camel Adventure Surakarta yang akan diterapkan serta dilakukan pemeliharaan sistem, dan mempertahankan kinerja sistem.

\subsection{Analisis Kelemahan Sistem}

Dari pengamatan yang dilakukan dan telah digambarkan sebelumnya, penulis menganalisa kelemahan sistem ini menggunakan kerangka PIECES yaitu Performance, Information, Economy, Control, Effesisy and Service. Analisa tersebut dapat dijelaskan sebagai berikut.

a. Performance (Kinerja)

Sistem yang lama masih menggunakan media kertas guna mencatat pemesanan yang dilakukan oleh pelanggan. Dilihat dari efisiensi waktu, pemesan harus datang langsung ke tempat Camel Adventure untuk mengetahui stok barang yang ada.

b. Information (Informasi)

Informasi yang disampaikan tidak update. Karena pelanggan harus mengunjungi tempat guna mendapatkan informasi secara langsung.

c. Economy (Ekonomi)

Biaya yang dikeluarkan relative lebih tinggi, karena masih menggunakan hard file dan harus menyediakan banyak kertas.

d. Control (Keamanan)

Keamanan data-data sangat kurang, karena data hanya disimpan didalam buku tentu saja rentan dengan hilang atau rusak karena sifat kertas yang mudah rusak.

e. Effesisy (Efisiensi)

Dalam pengerjaan transaksi penyewaan ditulis kedalam buku sehingga membutuhkan banyak waktu.

f. Service (Pelayanan)

Belum memberikan kemudahan dalam pengerjaan pendataan alat-alat outdoor.

2.3 Flowchart Sistem 


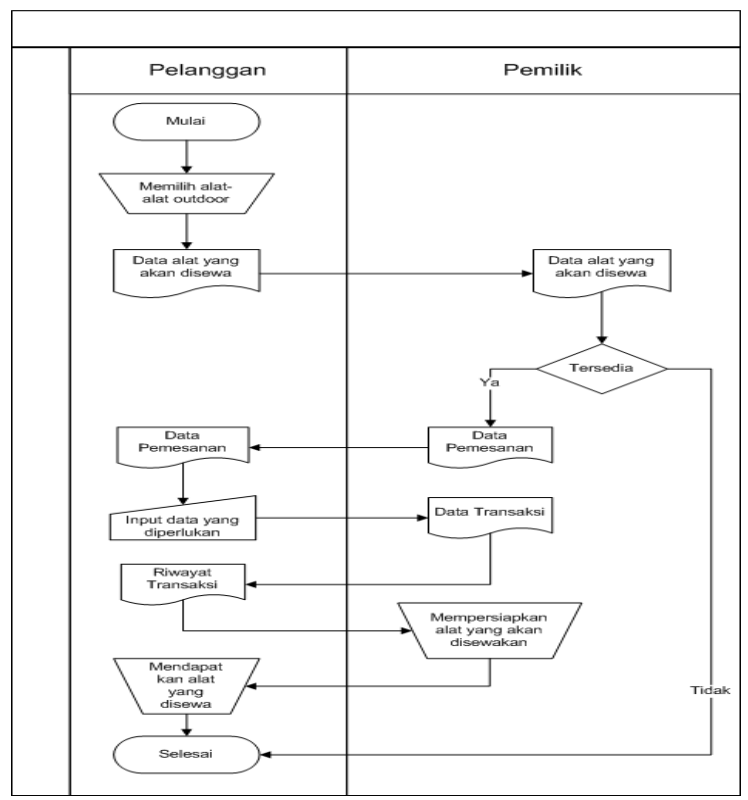

Gambar 2 Flowchart Sistem

Pada gambar 2 flowchart sistem yang dibangun, pelanggan memilih alat outdoor yang akan disewa pada aplikasi, apabila stok alat outdoor tersedia, pelanggan akan mendapatkan data pemesanan alat outdoor, selanjutnya pelanggan input data yang diperlukan, seperti lama waktu peminjaman dan jumlah alat outdoor yang akan disewa dan disimpan menjadi data transaksi. Pemilik mempersiapkan alat-alat outdoor yang akan disewa. Apabila stok alat outdoor tidak tersedia pelanggan memilih alat yang lain atau membatalkan transaksi.

2.4 Diagram Use Case

Usecase diagram mendiskripsikan sebuah interaksi antar satu atau lebih aktor dengan sistem yang akan dibuat. Usecase diagram mendefinisikan fitur dari sistem atau apa yang bisa dilakukan oleh sistem. Berikut gambar 3 usecase Diagram Rancang Bangun Aplikasi Penyewaan Alat Outdoor Berbasis Android Pada Camel Adventure:

\subsection{Relasi Antar Tabel}

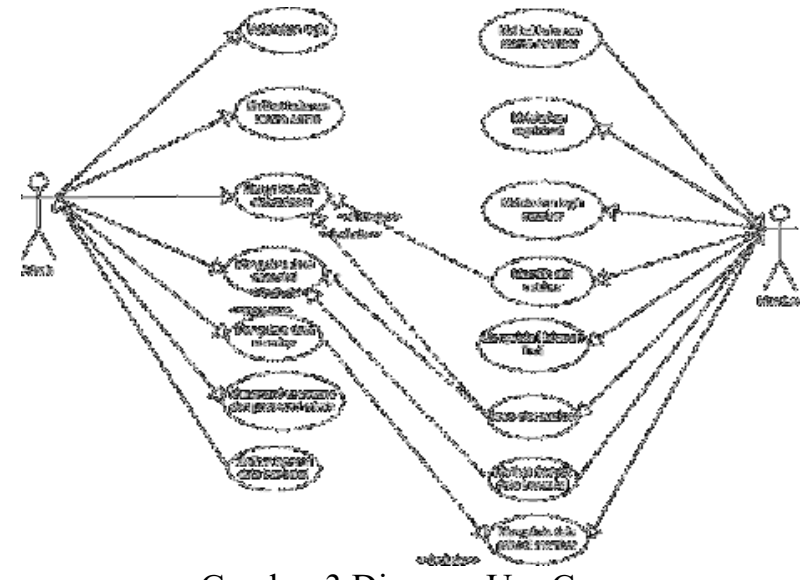

Gambar 3 Diagram Use Case

Relasi antar tabel adalah suatu desain interface untuk menggambarkan suatu relasi atau hubungan antar tabel yang saling berkaitan. Berikut ini gambar 4 adalah gambaran hubungan antar tabel Aplikasi Penyewaan Alat Outdoor Pada Camel Adventure Surakarta :

GO INFOTECH: JURNAL ILMIAH STMIK AUB Vol. 25, No. 2, Desember 2019: 71 - 81 


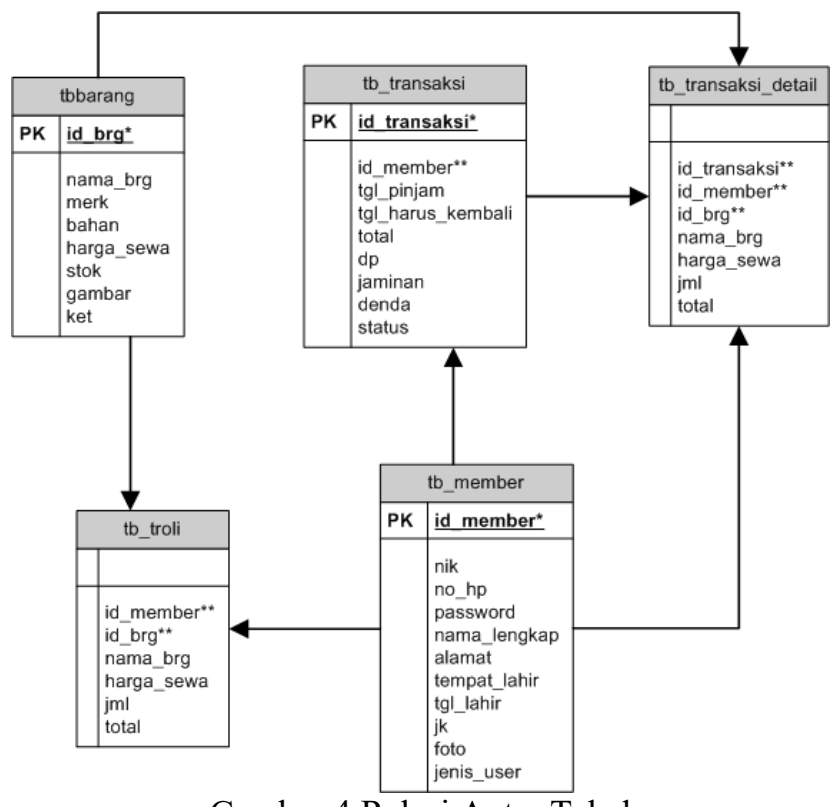

Gambar 4 Relasi Antar Tabel

Keterangan gambar 4 relasi antar tabel. Tbbarang sebagai tabel barang berhubungan dengan tbtroli sebagai tabel troli untuk menginput data pada troli dan pada tb_transaksi_detail sebagai tabel transaksi detail untuk detail transaksi. Tb_transaksi sebagai tabel transaksi berhubungan dengan tb_detail_transaksi sebagai tabel detail transaksi untuk mengambil data yang diperlukan. $\mathrm{Tb}$ member sebagai tabel member berhubungan dengan tb_troli sebagai tabel troli berguna untuk mengelola data troli dan berhubungan dengan tabel detail transaksi untuk menginput data yang diperlukan.

\section{HASIL DAN PEMBAHASAN}

\subsection{Hasil Penelitian}

Dalam pembuatan aplikasi ini dibutuhkan suatu implementasi untuk menguraikan program dan anlisi dari hasil program yang telah dibuat. Tujuan pembahasan ini adalah untuk mengetahui apakah program yang dibuat sudah bekerja seperti yang diharapkan atau belum. Berikut adalah proses pembahasan interface atau antarmuka program:

3.1.1 Antarmuka halaman berbasi web

\section{Halaman Login Admin}

Login Admin

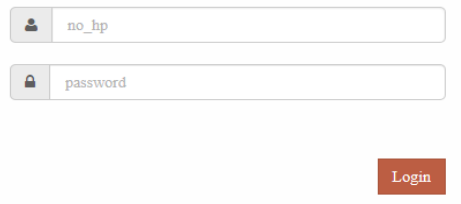

Gambar 5 Halaman Login Admin

Keterangan gambar 5 Halaman Login Admin. Bagian admin harus memasukan nomor handphone sebagai username dan password lalu klik tombol login. Jika username dan password 
benar maka sistem akan menampilkan halaman utama admin. Jika username dan password salah maka admin tidak dapat masuk pada halaman utama admin seperti pada gambar 6 .

2. Halaman Utama Admin

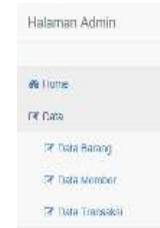

\section{SELAMAT DATANG DI HALAMAN ADMIN}

Gambar 6 Halaman Utama Admin

3. Halaman Data Barang

$$
\text { Heanan Admin }
$$

$$
\text { aime }
$$

scois

Th: isorameng

Q Sustiventer

Corstanes:

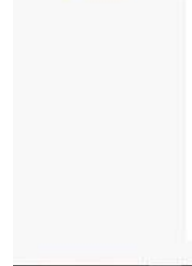

Data Transaksi

4. Halaman Data Transaksi

$$
\begin{aligned}
& \text { Helarran Admin } \\
& \text { at Hems } \\
& \text { a nasa } \\
& 6 \text { Dos Earos } \\
& 8 \text { byan venter } \\
& \text { arion ineson }
\end{aligned}
$$

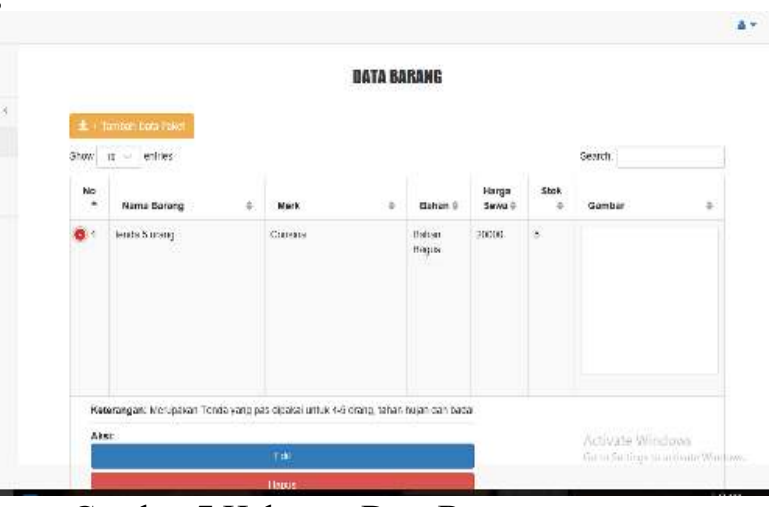

Gambar 7 Halaman Data Barang

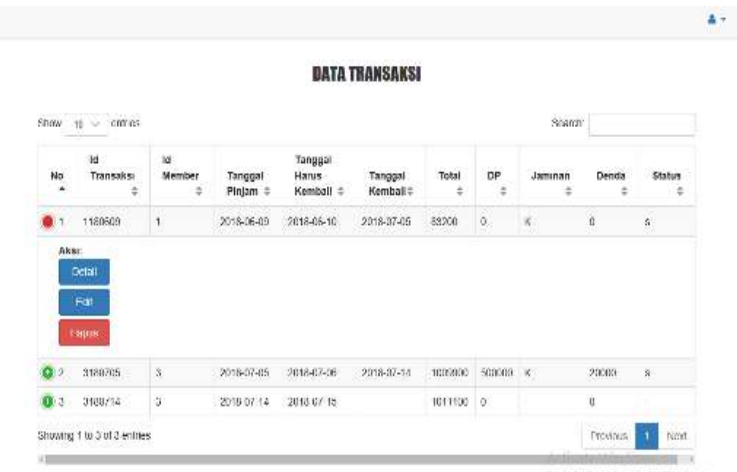

Gambar 8 Halaman Data Transaksi

3.1.2 Antarmuka halaman berbasis android

1. Halaman Utama

GO INFOTECH: JURNAL ILMIAH STMIK AUB Vol. 25, No. 2, Desember 2019: 71 - 81 


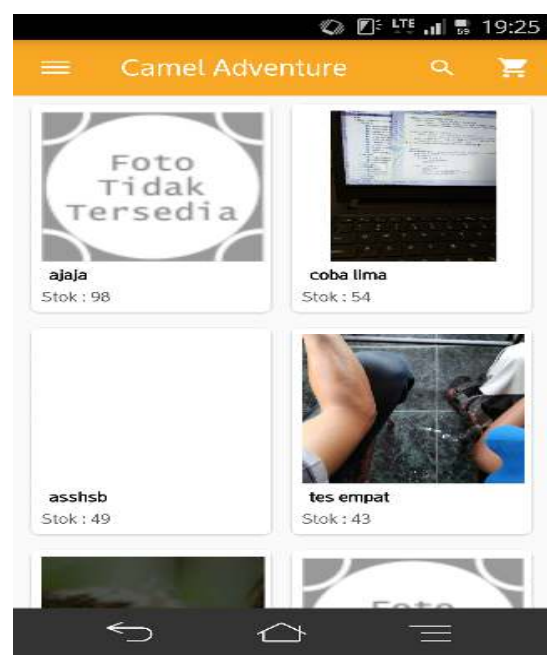

Gambar 9 Halaman Utama

Keterangan gambar 9 halaman Utama. Halaman utama menapilkan daftar alat-alat outdoor yang sudah diinput oleh admin sebagi pengelola aplikasi. Daftar alat-alat outdoor menampilkan gambar alat outdoor, nama alat outdoor, dan stok barang yang disediakan. Terdapat icon pencarian yang difungsikan sebagai tombol apabila klik tombol dapat mejalankan proses pencarian alat outdoor yang ditentukan dan klik icon keranjang atau troli untuk masuk pada halaman troli atau masuk ke halaman yang sudah ditentukan.

2. Halaman Troli
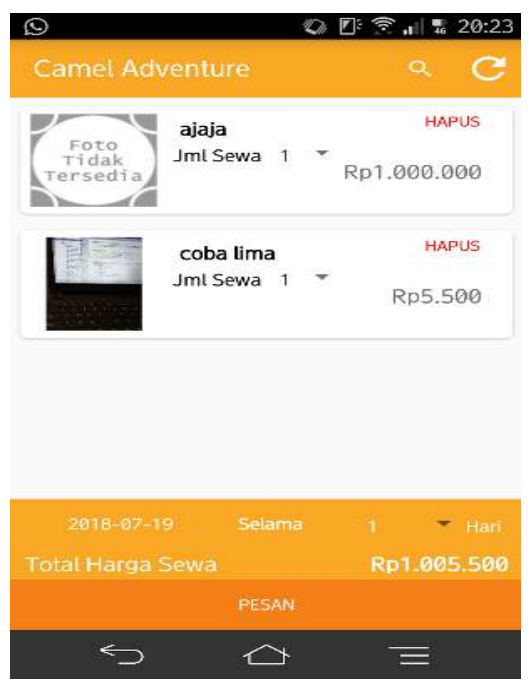

Gambar 10 Halaman Utama

Keterangan gambar 10 halaman troli berfungsi menampilkan data alat-alat outdoor yang sudah ditambahkan dan akan disewa oleh member. Pada halaman ini member bisa menghapus atau membatalkan apabila alat outdoor batal untuk disewa. Member bisa menetukan lama waktu peminjaman dan selanjutnya melakukan transaksi penyewaan. Klik tombol pesan untuk menyimpan data.

3. Halaman Profil Member 


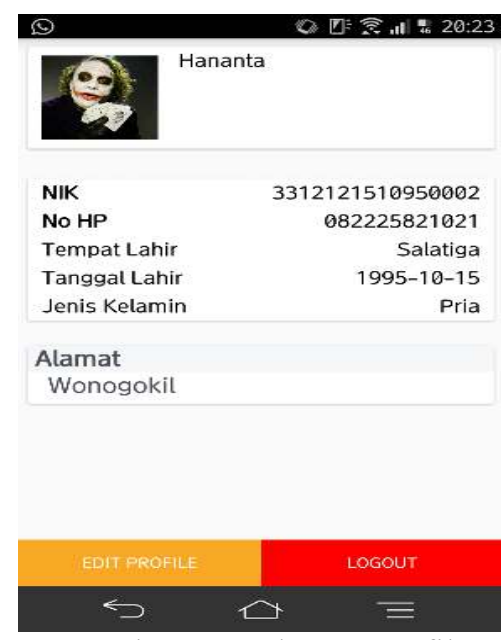

Gambar 11 Halaman Profil

4. Halaman Data Transaksi Member
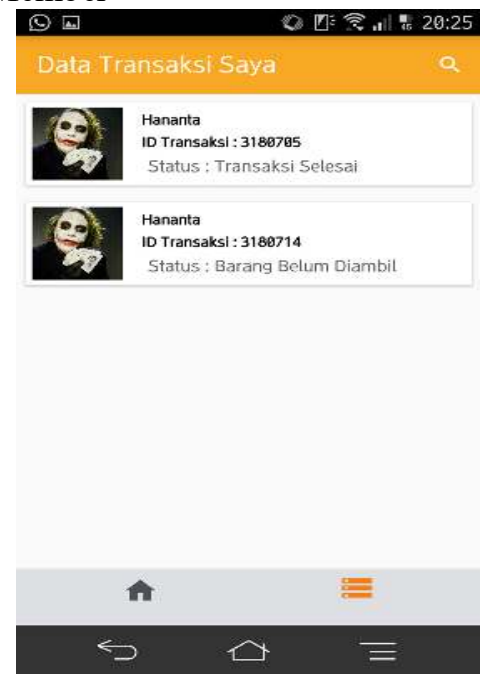

Gambar 12 Halaman Data Transaksi Member

Keterangan gambar 12 halaman Data Transaksi Saya berisi riwayat data transaksi yang sudah pernah dilakukan oleh member tersebut. Apabila di klik salah satu dari transaksi maka akan ditampilkan detail keseluruhan dari transaksi tersebut, seperti nama member, nomor transaksi, tanggal peminjaman, tanggal harus kembali, tanggal kembali, jaminan, DP, total, denda, grand total dan daftar atau list alat outdoor yang disewa.

5. Halaman Utama Admin Mengelola Data Alat Outdoor 


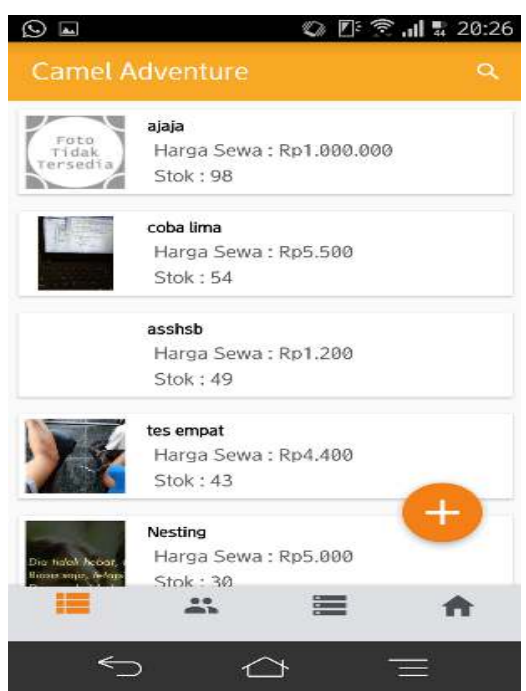

Gambar 13 Halaman utama Admin mengelola mata alat outdoor

Pada gambar 13 halaman utama Admin mengelola mata alat outdoor. Setelah admin melakukan proses login maka akan tampil halaman utama tersebut. Pada halaman utama terdapat data alatalat outdoor. Klik salah satu data untuk menampilkan detail data barang tersebut.

6. Admin Detail Data Transaksi

\begin{tabular}{|c|c|}
\hline (2) $\square$ & 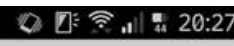 \\
\hline \multicolumn{2}{|c|}{ Hananta } \\
\hline TELP & SMS \\
\hline No Transaksi & 3180714 \\
\hline Tgl Pinjam & 2018-07-14 \\
\hline Tgl Harus Kembali & 2018-07-15 \\
\hline Tanggal Kembali & null \\
\hline Jaminan & - \\
\hline DP & $\mathrm{Rp} 0$ \\
\hline Total & Rp1.011.100 \\
\hline Denda & $\mathrm{Rp} 0$ \\
\hline Grand Total & Rp1.011.100 \\
\hline \multicolumn{2}{|c|}{ List Barang } \\
\hline \multicolumn{2}{|c|}{ LIHAT LIST BARANG } \\
\hline \multicolumn{2}{|c|}{ Konfirmasi } \\
\hline \multicolumn{2}{|c|}{ KONFIRMASI BARANG DIAMBIL } \\
\hline$\leftrightarrows$ & $\equiv$ \\
\hline
\end{tabular}

Gambar 14 Halaman Admin Detail Data Transaksi

Didalam halaman detail data transaksi gambar 14 terdapat beberapa informasi atau data dan beberapa tombol sebagai berikut:

a) Informasi yang menampilkan foto, nama, dan nomor handphone member yang melakukan transaksi. 
b) Informasi yang menampilkan nomor transaksi, tanggal peminjaman, tanggal harus kembali, tanggal kembali, jaminan, DP (Down Payment) atau disebut uang muka, total biaya, denda apabila terjadi keterlambatan dan grand total.

c) Klik tombol list barang yang berfungsi menampilkan data barang yang disewa.

d) Klik tombol konfirmasi yang berfungsi mengkonfirmasi data transaksi member.

\section{KESIMPULAN}

Hasil Rancang Bangun Aplikasi Penyewaan Alat Outdoor pada Camel Adventure menggunakan Flowchart, UML (Unified Modeling Language) yang tediri dari Usecase Diagram, Activity Diagram, Sequence Diagram, Class Diagram, dan Entity Relationship Diagram. Sedangkan untuk metode pengembangan sistem menggunakan Metode Waterfall. Pengembangan sistem menggunakan bahasa pemrograman PHP dan Java, database menggunakan MySQL, aplikasi pendukung Android Studio Versi 3.0.1 dan Notepad++ Sistem ini bisa melakukan pengolahan data alat-alat outdoor, pengolahan data member dan pengolahan data transaksi. Aplikasi Penyewaan Alat Outdoor sudah diimplementasikan pada Camel Adventure sebagai instansi tempat penelitian dan sudah memenuhi harapan dalam hal perancangan dan pengembangan sistem. Adanya Aplikasi Penyewaan Alat Outdoor pada Camel Adventure memberikan media baru bagi pelanggan dalam menyediakan informasi alat-alat outdoor yang disewakan. Selain itu dapat melakukan transaksi penyewaan alat outdoor tersebut. Sehingga dapat memudahkan pelanggan untuk mendapatkan informasi tersebut.

\section{SARAN}

Aplikasi Penyewaan Alat Outdoor pada Camel Adventure ini masi dapat dikembangkan lebih lanjut, yaitu dengan menambahkan informasi lokasi langsung dari google map, menambahakan metode pembayaran pada aplikasi, menggunakan via transfer ataupun melalui metode yang lain. Menambahkan informasi foto data alat outdoor dalam bentuk 3D atau tiga dimensi.

\section{DAFTAR PUSTAKA}

[1] Aliminsyah Dkk, 2002. Ekonomi Mikro, Yogyakarta: Yayasan Obor

[2] Nugroho, Adi. 2006. E-commerce. Informatika Bandung. Bandung.

[3] Arief, M.Rudianto. 2011. Pemrograman Web Dinamis Menggunakan Php dan Mysql.Yogyakarta: Andi.

[4] Coupey, Eloise. 2001. Marketing and the internet. PenticeHall, Inc. New Jersy.

[5] Decoster. 2012. Pengertian JavaDevelopment Kit :http://library.binus.ac.id diakses pada 2 Oktober 2017.

[6] Grounlund, Nourman E dan Linn, Robert L. 1985. Measurement and Evaluation in Teaching. New York: McMillan Publishing Company.

[7] Haryanto, Bambang . 2011:2. Esensi-esensi Bahasa Pemrograman Java. Yogyakarta: Andi.

[8] Jeffrey. L. Whitten, Lonnie D.Bentley, Kevin C. 2001. System Analysis and Design Methods 5thEd. McGraw-Hill.

[9] Jogiyanto. 2005. Analisis \& Deasin Sistem Informasi.:Pendekatan Terstruktur Teori dan Praktek Aplikasi Bisnis. Yogyakarta: Andi.

[10] Kristanto. 2003. Konsep dan Perancangan Basis Data. Yogyakarta: Andi.

[11] Sommerville, Ian. 2011. Software Engineering (Rekayasa Perangkat Lunak). Jakarta : Erlangga.

[12] Umar, Husein. 2003. Metode Riset Komunikasi Organisasi. Bandung: PT. Gramedia Pustaka Utama.

GO INFOTECH: JURNAL ILMIAH STMIK AUB Vol. 25, No. 2, Desember 2019: 71 - 81 
[13] Shalahuddin, M dan Rosa. 2015. Rekayasa Perangkat Lunak Tersruktur dan Berorientasi Objek. Bandung: Informatika.

[14] Zufri Halim, Muh, 2013. Rancang Bangun Sistem Informasi Penyewaan Pada Rental Mobil Berbasis Web dan Menggunakan SMS Getway.

[15] Safaat, Nazruddin. 2012. Android Pemrograman Aplikasi Mobile Smartphone dan Tablet PC Berbasis Android . Bandung: Informatika Bandung.

[16] Sandi. 2012. Definisi Pengertian dan Fungsi XAMPP Lengkap. https://indoskripsi.com diakses pada 22 November 2017.

[17] Ahmad Arid, Robeth. 2016. Perancangan Sistem Informasi Penyewaan Alat-Alat Outdoor Di Toko Rent Outdoor \& Equpment Berbasis Web.

[18] Pressman, Roger S. 2001.Rekayasa Perangkat Lunak Pendekatan Praktisi. Yogyakarta: Andi.

[19] Shalahuddin, M dan Rosa. 2015. Rekayasa Perangkat Lunak Tersruktur dan Berorientasi Objek. Bandung: Informatika.

[20] Sukimo, Sadono, 2003. Pengantar Teori Mikro Ekonomi. Jakarta: PT. Salemba Empat

[21] Hasan, Sarip. 2016. Sistem Informasi Penyewaan Alat-Alat Camping Pada TankBaja Outdoor Berbasis Website.

[22] Wikipedia. 2017. Aplikasi. https://id.wikipedia.org/wiki/Aplikasi diakses pada 26 Oktober 2017. 